\title{
Diffuse bowel uptake of 18F-FDG on PET/CT examination of a patient with diabetes treated with metformin
}

\author{
Thomas Bevilacqua, ${ }^{1}$ Gary Stuart Greene ${ }^{2}$
}

${ }^{1}$ Department of Radiology, Pennsylvania Hospital, Philadelphia, Pennsylvania, USA

2Department of Radiology/ Nuclear Medicine, Pennsylvania Hospital, University of Penn Health System, Philadelphia Pennsylvania, USA

\section{Correspondence to}

Dr Gary Stuart Greene, greeneg@pahosp.com

Accepted 16 March 2014

\section{DESCRIPTION}

A patient with a history of non-abdominal malignancy presented after treatment for a follow-up PET/CT scan. Pertinent medical history included essential hypertension and type II diabetes mellitus. The patient's medications included metformin, furosemide and metoprolol. The PET/CT scan demonstrated diffusely increased 18-FDG uptake throughout the small and large intestine with SUVs of up to 21.3 (figure 1). The differential diagnosis for increased bowel uptake on PET/CT examination is broad and includes neoplasm, infection and inflammation with a myriad of aetiologies. However, diffuse, intense bowel uptake in a patient with diabetes is characteristic of uptake secondary to treatment with metformin.

Metformin (dimethylbiguanide) is an oral biguanide used to treat diabetes mellitus. In a rodent model, metformin treatment increased intestinal glucose uptake by up to $60 \%$ in hyperglycaemic conditions, which likely accounts for the imaging findings. ${ }^{1}$ A recent study shows cessation of metformin 2 days before PET/CT examination markedly decreased the level of intestinal uptake without adversely effecting blood glucose levels. ${ }^{2} 3$

As the role of PET/CT in the management of malignancy continues to increase, understanding potential pitfalls and normal variation will be crucial for its successful implementation. Concurrently, a worldwide obesity epidemic has developed over the past decades resulting in a huge increase in type II diabetes mellitus, especially in the Western world. Therefore, an understanding of this interesting and potentially limiting PET/CT finding associated with the use of metformin, an extremely common agent used for the treatment of type II diabetes, will be crucial to the successful acquisition and interpretation of these studies.
To cite: Bevilacqua $\mathrm{T}$, Greene GS. BMJ Case Rep Published online: [please include Day Month Year] doi:10.1136/bcr-2013202058

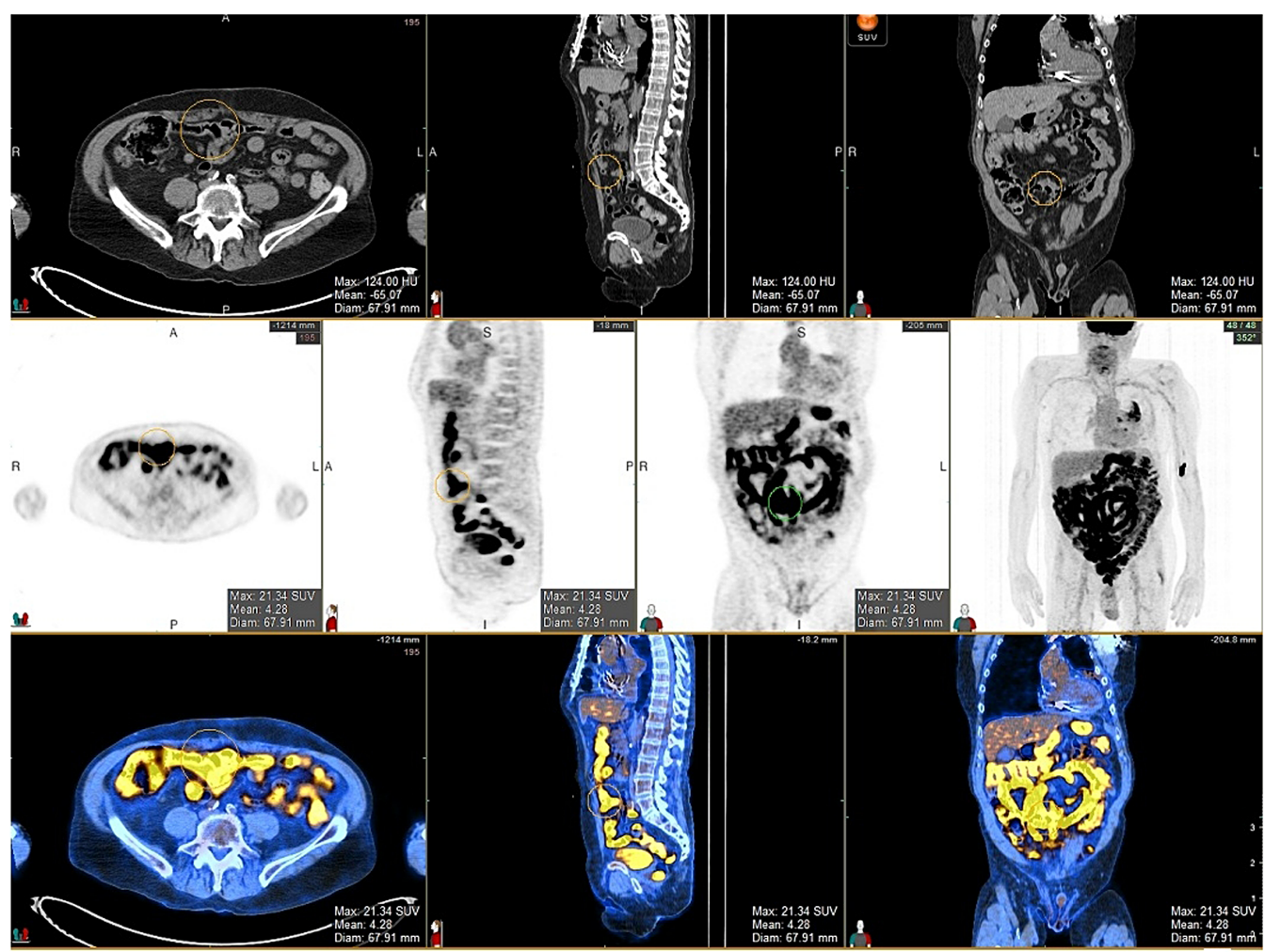

Figure 1 Multiplanar CT, PET and overlay images of the abdomen reveal intense uptake of 18-FDG throughout the visualised bowel, secondary to metformin therapy. 


\section{Learning points}

- Metformin therapy can cause diffuse uptake of 18F-FDG throughout the bowel.

- If abdominal pathology is suspected, awareness of this possible confounding factor is necessary to avoid suboptimal examination due to obscuration of the pathology by diffuse bowel uptake.

- Stopping metformin therapy for 2 days before PET/CT examination eliminates bowel uptake without adversely affecting blood glucose levels.
Competing interests None.

Patient consent None.

Provenance and peer review Not commissioned; externally peer reviewed.

\section{REFERENCES}

1 Gontier E, Fourme E, Wartski M, et al. High and typical 18F-FDG bowel uptake in patients treated with metformin. Eur J Nucl Med Mol Imaging 2008;35:95-9.

2 Oh JR, Song HC, Chong A, et al. Impact of medication discontinuation on increased intestinal FDG accumulation in diabetic patients treated with metformin. AJR Am J Roentgenol 2010;195:1404-10.

3 Özülker T, Özülker F, Mert M, et al. Clearance of the high intestinal 18F-FDG uptake associated with metformin after stopping the drug. Eur J Nucl Med Mol Imaging 2010;37:1011-17.

Copyright 2014 BMJ Publishing Group. All rights reserved. For permission to reuse any of this content visit http://group.bmj.com/group/rights-licensing/permissions.

BMJ Case Report Fellows may re-use this article for personal use and teaching without any further permission.

Become a Fellow of BMJ Case Reports today and you can:

- Submit as many cases as you like

- Enjoy fast sympathetic peer review and rapid publication of accepted articles

- Access all the published articles

- Re-use any of the published material for personal use and teaching without further permission

For information on Institutional Fellowships contact consortiasales@bmjgroup.com

Visit casereports.bmj.com for more articles like this and to become a Fellow 